\title{
Trunk muscular endurance, lumbar spine mobility and hip flexibility in sailors with and without low back pain
}

\author{
Análise da resistência muscular do tronco, mobilidade da coluna \\ lombar e flexibilidade do quadril em velejadores com e sem dor lombar
}

\author{
Laís Marinho de Araújo (D), Elisa Dell'Antonio (D), Marcel Hubert ${ }^{(D)}$, Caroline Ruschel (D), \\ Helio Roesler ${ }^{(D)}$, Suzana Matheus Pereira $(\mathbb{D} *$
}

Universidade do Estado de Santa Catarina (UDESC), Florianópolis, SC, Brazil

\begin{abstract}
Introduction: Low back pain is one of the most common injuries in sailors. Findings in the literature indicate that poor trunk endurance, flexibility and muscle strength are common in individuals with low back pain (LBP). Objective: Analyze trunk muscle endurance, lumbar spine mobility and hip flexibility in windsurfers with and without low back pain. Method: Sailors of both sexes with at least three years' experience in the sport answered the Nordic Musculoskeletal Questionnaire and were submitted to Schober's test, the passive straight leg raise (PSLR), the modified Thomas test, and isometric endurance assessment of the flexor, extensor and lateral flexor muscles of the torso. The sailors were divided into two groups (with and without LBP) and compared using the Student's t-test or Mann Whitney U test. Results: Participants were 22 national-level sailors, 11 with low back pain (LBP) and 11 without (NLBP). The LBP group obtained longer holding times for the trunk extensors $(p=0.028)$ and a greater difference in endurance between the right and left sides for lateral trunk muscles $(\mathrm{p}=0.030)$. Both groups obtained results below normative values in most of the tests performed. Conclusion: Sailors with low back pain exhibited greater trunk extensor
\end{abstract}

*LMA: MS, e-mail: laismarinho_fisio@hotmail.com

EDA: PhD, e-mail: elisa.antonio@udesc.br

MH: PhD, e-mail: marcel.hubert@udesc.br

CR: PhD, e-mail: caroline.ruschel@udesc.br

HR: PhD, e-mail: helio.roesler@udesc.br

SMP: PhD, e-mail: suzana.pereira@udesc.br 
endurance and a larger imbalance between lateral trunk muscles when compared to those with no LBP. Spinal mobility and hip flexibility were similar between groups.

Keywords: Back Pain. Sports. Rehabilitation. Stabilization.

\section{Resumo}

Introdução: A dor lombar é uma das lesões que mais afeta os velejadores. Achados na literatura mostram que a deficiência de força do tronco, flexibilidade e resistência muscular é comum em indivíduos com dor lombar. objetivo: Analisar a resistência muscular do tronco, a mobilidade da coluna lombar e a flexibilidade do quadril em velejadores com e sem dor lombar. Método: Velejadores de ambos os sexos e com no mínimo três anos de prática responderam ao questionário nórdico de lesões osteomusculares e realizaram os testes de Schöber, de Elevação Passiva da Perna Estendida, de Thomas Modificado e de resistência isométrica dos músculos flexores, extensores e laterais do tronco. Os velejadores foram divididos em dois grupos (com e sem dor lombar), comparados por meio do teste t de Student para amostras independentes ou U de Mann Whitney. Resultados: 22 velejadores de nível nacional, $11 \mathrm{com}$ dor lombar (CDL) e $11 \mathrm{sem}$ dor lombar (SDL), participaram do estudo. O grupo CDL apresentou maior tempo de permanência no teste de resistência dos extensores do tronco $(p=0,028)$ e maior diferença entre os lados direito e esquerdo no teste de resistência dos músculos laterais do tronco $(p=0,030)$. Na maioria dos testes realizados, os dois grupos apresentaram resultados abaixo dos valores normativos. Conclusão: Velejadores com dor lombar apresentaram maior resistência dos extensores do tronco, porém maior desequilíbrio entre as cadeias laterais do tronco, em comparação a velejadores sem dor lombar. A mobilidade da coluna e a flexibilidade do quadril foram semelhantes entre os grupos.

Palavras-chave: Dor Lombar. Esporte. Reabilitação. Estabilização.

\section{Introduction}

Low back pain (LBP) is a worldwide problem [1, 2], affecting athletes in a wide range of sports [2 4]. Recent studies have shown that the prevalence of LBP in athletes varies by sport [4]. In sailors, the frequency of musculoskeletal symptoms and injuries is between 11 and 52.9\% [5 - 7]. Over a 12-month period, the lumbar spine was the site of $23 \%$ of injuries that required medical attention and 33\% of those that prevented athletes from engaging in their chosen sport for a certain time [8]. In sailing, pain episodes are generally associated with sailing in strong winds, dynamic hiking, the latter stages of the annual training season and/or sailing career [8].

The physical demands on Olympic class sailors in regattas are significant from both a physiological and a biomechanical perspective $[9,10]$, varying in accordance with the type of boat and prevailing wind.
In some instances, sailors remain in the hiking position for $50 \%$ of the total race time [11 - 13]. Hiking involves leaning outside of the boat to compensate for the torque generated by the wind and water in order to stabilize the vessel.

Findings in the literature indicate that sports requiring repeated hyperextension of the spine have a high incidence of low back pain [9 - 12]. In this respect, low trunk extensor endurance is a known predictor of LBP [14 - 16] and abdominal muscle weakness or fatigue may result in greater hip flexor muscle recruitment and activity during hiking. This tends to promote lordosis, resulting in high compression and shearing forces, which act on the posterior surface of the vertebrae and intervertebral discs, thereby increasing the potential risk of chronic injury [8]. 
Although some studies have found no relationship between LBP and reduced hamstring flexibility $[17,18]$, Kendal [19] and Bellew [20] reported that shortened hamstrings rotate the pelvis posteriorly, reduce lumbar curvature, alter the lumbopelvic rhythm and generate compensatory movement in the lumbar spine, which can trigger low back pain.

Musculoskeletal complaints, especially LBP, are common health problems in sailors of different classes [21]. In light of the above, this study aimed to analyze trunk muscle endurance, lumbar spine mobility and hip flexibility in sailors with and without low back pain.

\section{Method}

\section{Participants}

Participants in this cross-sectional study were sailors of both sexes with at least three years' experience in the sport. Those with a history of spinal, hip or lower limb injuries or surgeries were excluded. The sample consisted of sailors from different sailboat classes who took part in the Copa Brasil de Vela (Brazilian Sailing Cup), held in Rio de Janeiro state (RJ), and Campeonato Brasileiro de Optimist (Brazilian Optimist Championship) in Florianópolis, Santa Catarina state (SC). All participants provided written informed consent and the study was approved by the institutional Research Ethics Committee (protocol number 1.351.240).

\section{Instruments and Tests}

Anthropometric measurements (weight and height) were obtained using a mechanical balance with a resolution of $0.1 \mathrm{~kg}$ (Welmy) and $1 \mathrm{~mm}$ resolution stadiometer (Welmy).

Schober's test (Figure 1) was applied to assess spinal mobility, with participants standing at maximal spinal flexion. The reference points were near the fifth lumbar vertebra (between the posterior superior iliac spines) and $10 \mathrm{~cm}$ above this point. The test was considered normal when there was a difference of five or more centimeters between standing upright and at maximal lumbar

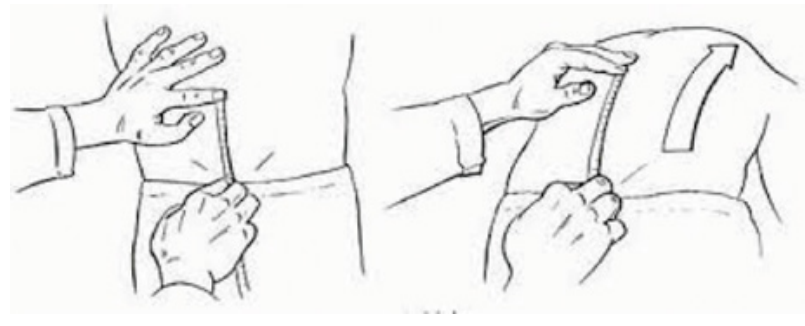

Figure $\mathbf{l}$ - Diagram of the measurement procedure according to Schober's test.

Note: http://www.painneck.com/ankylosing-spondylitis-diagnosis.

The passive straight leg raise (PSLR) evaluates hamstring flexibility and was applied based on Kendall [19] and Gajdosik [24]. A digital camera (Canon ${ }^{\circledR}$ D10) was positioned perpendicular to and three meters away from the sagittal plane of the subject, focused on the lateral epicondyle of the femur of the leg assessed. Markers were placed on the following anatomical points: greater trochanter of the femur (GTF), lateral epicondyle of the femur (LEF) and lateral malleolus (LM). The measurement was determined by the angle formed between the GTFLEF-LM lines and the horizontal plane.

The modified Thomas test, widely used to assess hip extension flexibility, involves objective analysis of the shortening of muscle-tendon units of the uni- and biarticular hip flexors [23, 24]. Analysis was based on a digital photograph (Olympus Camedia Master ${ }^{\circledR}$ ). The anatomical points used were the same as those described for the PSLR test. These points were delimited to define the thigh (greater trochanter and lateral epicondyle of the femur) and leg segments (femoral epicondyle and fibular malleolus) and the joint angles quantified based on a system of coordinates obtained with Kinovea ${ }^{\circledR}$ software (version 20.0).

Torso flexor, lateral flexor and extensor endurance (Figure 2) were evaluated based on how long the isometric positions were maintained (holding time). The maximum holding time was standardized at 5 minutes ( 300 seconds) followed by a 5 -minute rest between tests.

The flexors and lateral flexors were assessed using the tests proposed by McGill [25], calculating the difference between the right and left sides as an indicator of lateral trunk stability. Trunk extensor 


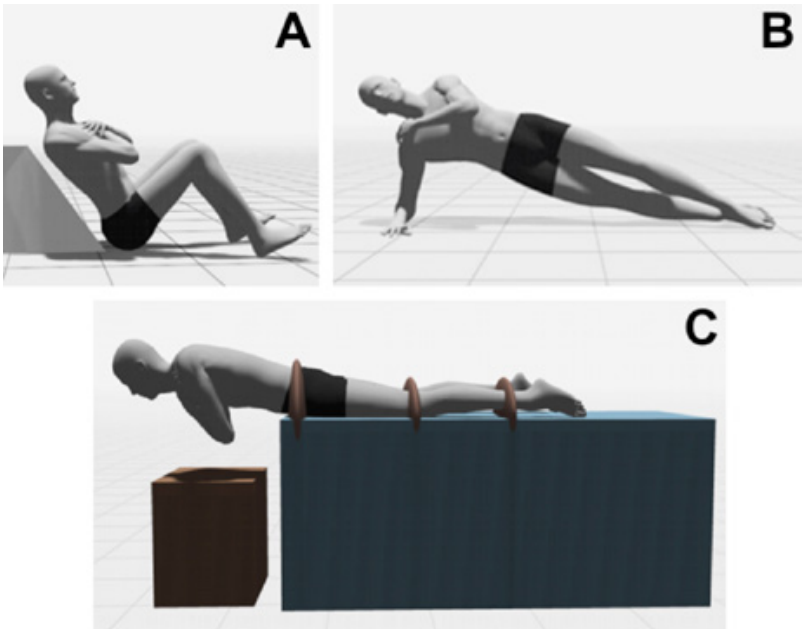

Figure 2 - Images of the isometric positions adopted in torso flexor (A), lateral flexor (B) and extensor (C) tests.

Note: Created by the authors using the Magic Poser Web application (Wombat Studio Inc.).

In addition to being recommended in the literature, this battery of tests is also operationally viable for a field study.

An electrical goniometer was used to measure a $10^{\circ}$ angle of the trunk during the test (Noraxon ${ }^{\circledR}$ Inline 1D/2D, U.S.A), positioned at the mid-axillary line of the torso at the level of the anterior superior iliac spine, and providing visual feedback to the subject during execution. The difference between the results obtained for flexors and extensors was calculated as an indicator of anterior-posterior stability of the trunk.

\section{Procedures}

Initially participants were taken to a private room where they filled out an anamnesis questionnaire regarding their involvement in sailing as well as the Nordic Musculoskeletal Questionnaire [22]; the answers were used to divide them into the LBP and NLBP groups.

Next, anthropometric measurements were taken (height and weight) and the anatomical landmarks of interest marked. The subjects then changed into swimwear for the lumbar spine mobility (Schober's test) and passive flexibility assessments (modified Thomas test and PSLR), under the supervision and guidance of the researchers.

Finally, they performed the isometric endurance tests of the torso flexors, lateral flexors (left and right) and extensors, in random order. The position to be maintained was demonstrated before each test and participants were allowed time to familiarize themselves with it. A 5-minute rest was given after valid execution of each test and verbal encouragement was provided by the researchers.

\section{Statistical analysis}

Descriptive (mean, standard deviation, 95\% confidence interval, median and interquartile range) and inferential statistics were used. Normal data distribution was checked by the Shapiro-Wilk test. The variables of interest were compared between groups using the Student's t-test for normal data and the Mann Whitney U test for data with non-normal distribution. Effect size was estimated using Cohen's d and interpreted as follows: 0.0 to 0.1 - no effect; 0.2 to 0.5 - small effect; 0.5 to 0.8 - moderate effect; and $\geq 0.8$ - large effect. The Statistical Package for the Social Sciences (SPSS 20.0 for Windows) was used for all the tests, with a 95\% confidence interval $(\mathrm{p} \leq 0.05)$.

\section{Results}

Participants were 22 Brazilian sailors of both sexes, from the monotype (Optimist, Laser, 29er, Nacra and 420 ) and windsurfing classes (RS:X), with $4.7 \pm 0.6$ years' experience in the sport and $3.8 \pm 0.9$ training sessions a week, lasting $3.4 \pm 0.7$ hours each. Of these, 11 (two women and nine men) were allocated to the group with no low back pain symptoms (NLBP) and 11 (four women and seven men) to the low back pain group (LBP), in accordance with the previously described criteria. The participants' characteristics are described in Table 1.

Table 1 - Mean \pm standard deviation of participant characteristics

\begin{tabular}{lcccc}
\hline & $\begin{array}{c}\text { All Participants } \\
(\mathbf{n}=\mathbf{2 2})\end{array}$ & $\begin{array}{c}\text { NLBP } \\
(\mathbf{n}=\mathbf{1 1})\end{array}$ & $\begin{array}{c}\text { LBP } \\
(\mathbf{n}=\mathbf{1 1})\end{array}$ & $\mathbf{p}^{*}$ \\
\hline Age (years) & $18.8 \pm 2.9$ & $19.1 \pm 3.5$ & $18.5 \pm 2.1$ & 0.614 \\
Weight $(\mathrm{kg})$ & $65.0 \pm 11.6$ & $64.9 \pm 13.1$ & $65.2 \pm 10.6$ & 0.952 \\
Height $(\mathrm{cm})$ & $1.74 \pm 0.10$ & $1.74 \pm 0.11$ & $1.74 \pm 0.11$ & 0.968 \\
\hline
\end{tabular}

Note: NLBP: sailors with no low back pain symptoms; LBP: sailors with low back pain symptoms; ${ }^{p}$-value obtained on intergroup comparison using the Student's t-test for independent samples. 
Mobility and flexibility

Analysis of spinal mobility and hamstring and hip flexor muscle (uni- and biarticular) flexibility revealed no significant intergroup differences, as shown in Table 2.

Table 2 - Mean \pm standard deviation ( $95 \%$ confidence interval - 95\%CI) of the variables obtained in the mobility and flexibility test; mean difference $(95 \% \mathrm{CI})$, $\mathrm{p}$-value and effect size for intergroup comparison

\begin{tabular}{lccccc}
\hline \multicolumn{1}{c}{ Variable } & NLBP & LBP & $\begin{array}{c}\text { Mean } \\
\text { difference }\end{array}$ & $\mathbf{p}$ & Effect size \\
\hline Lumbar spine mobility $(\mathrm{cm})$ & $15.2 \pm 0.9$ & $14.9 \pm 1.0$ & 0.32 & $0.429^{\mathrm{a}}$ & 0.683 \\
& $(14.6-15.8)$ & $(14.3-15.6)$ & $(-0.5-1.1)$ & & \\
& $61.6 \pm 9.9$ & $72.3 \pm 15.8$ & -10.7 & $0.071^{\text {a }}$ & -0.81 \\
Passive straight leg raise - right leg $\left(^{\circ}\right)$ & $(54.9-68.2)$ & $(61.7-82.9)$ & $(-22.4-1.0)$ & & \\
& $61.8 \pm 6.7$ & $72.6 \pm 17.8$ & -10.8 & $0.082^{\text {a }}$ & -0.80 \\
Passive straight leg raise - left leg $\left(^{\circ}\right)$ & $(57.3-66.3)$ & $(60.7-84.6)$ & $(-23.2-1.6)$ & & \\
& $5.8 \pm 3.5$ & $4.2 \pm 3.4$ & 1.6 & $0.278^{\text {a }}$ & 0.46 \\
Uni hip flexors - right side $\left(^{\circ}\right)$ & $(3.5-8.2)$ & $(1.9-6.5)$ & $(-1.4-4.7)$ & & \\
& $6.0 \pm 2.3$ & $5.0 \pm 3.2$ & 1.0 & $0.411^{\text {a }}$ & 0.36 \\
Uni hip flexors - left side $\left(^{\circ}\right)$ & $(4.5-7.5)$ & $(2.8-7.2)$ & $(-1.5-3.5)$ & & \\
& $10.3 \pm 6.4$ & $10.9 \pm 4.4$ & -0.6 & $0.788^{\text {a }}$ & -0.11 \\
Bi hip flexors - right side $\left(^{\circ}\right)$ & $(6.0-14.6)$ & $(8.0-13.9)$ & $(-5.5-4.2)$ & & \\
& $10.6 \pm 6.0$ & $13.4 \pm 4.9$ & -2.8 & $0.242^{\text {a }}$ & -0.52 \\
Bi hip flexors - left side $\left(^{\circ}\right)$ & $(6.5-14.6)$ & $(10.0-16.7)$ & $(-7.7-2.1)$ & \\
\hline
\end{tabular}

Note: NLBP: sailors with no low back pain symptoms; LBP: sailors with low back pain symptoms; Uni: uniarticular; Bi: Biarticular; *p-value obtained on intergroup comparison using the Student's t-test for independent samples.

\section{Isometric trunk endurance}

The results of trunk endurance testing are presented in Table 3. A significant difference was only recorded for trunk extensor endurance, indicating better performance for the LBP when compared to the NLBP.
Although no intergroup difference was observed for the results of the right and left lateral flexors in individual tests, there was a significant difference and large effect size in terms of the balance between these muscles.

Table 3 - Mean \pm standard deviation (95\% confidence interval - 95\%CI) of the variables obtained in the mobility and flexibility test; mean difference $(95 \% \mathrm{CI})$, p-value and effect size for intergroup comparison

\begin{tabular}{|c|c|c|c|c|c|}
\hline Variable & NLBP & LBP & $\begin{array}{c}\text { Mean } \\
\text { difference }\end{array}$ & p & Effect size \\
\hline Lateral Endurance - R (s) & $\begin{array}{c}15.2 \pm 0.9 \\
(14.6-15.8)\end{array}$ & $\begin{array}{c}14.9 \pm 1.0 \\
(14.3-15.6)\end{array}$ & $\begin{array}{c}-37.5 \\
(-99.0-24.0)\end{array}$ & $0.332^{b}$ & -0.55 \\
\hline Lateral Endurance - L (s) & $\begin{array}{c}61.6 \pm 9.9 \\
(54.9-68.2)\end{array}$ & $\begin{array}{l}72.3 \pm 15.8 \\
(61.7-82.9)\end{array}$ & $\begin{array}{c}-10.0 \\
(-55.5-35.5)\end{array}$ & $0.699^{b}$ & -0.16 \\
\hline Lateral L-R balance & $\begin{array}{c}61.8 \pm 6.7 \\
(57.3-66.3)\end{array}$ & $\begin{array}{l}72.6 \pm 17.8 \\
(60.7-84.6)\end{array}$ & $\begin{array}{c}-23.6 \\
(-44.5--2.7)\end{array}$ & $0.030^{\mathrm{a}}$ & -1.05 \\
\hline Flexor Endurance (s) & $\begin{array}{l}5.8 \pm 3.5 \\
(3.5-8.2)\end{array}$ & $\begin{array}{c}4.2 \pm 3.4 \\
(1.9-6.5)\end{array}$ & $\begin{array}{c}-58.8 \\
(-127.0-9.3)\end{array}$ & $0.193^{b}$ & -0.53 \\
\hline Extensor Endurance (s) & $\begin{array}{c}6.0 \pm 2.3 \\
(4.5-7.5)\end{array}$ & $\begin{array}{l}5.0 \pm 3.2 \\
(2.8-7.2)\end{array}$ & $\begin{array}{c}-65.0 \\
(-116.4--13.6)\end{array}$ & $0.028^{b}$ & -1.12 \\
\hline F-Ex Balance & $\begin{array}{c}10.3 \pm 6.4 \\
(6.0-14.6)\end{array}$ & $\begin{array}{l}10.9 \pm 4.4 \\
(8.0-13.9)\end{array}$ & $\begin{array}{c}-1.5 \\
(-70.5-67.6)\end{array}$ & $0.965^{\mathrm{a}}$ & -0.02 \\
\hline
\end{tabular}

Note: NLBP: sailors with no low back pain symptoms; LBP: sailors with low back pain symptoms; R: right side; L - left side; F: Flexors; Ex: Extensors; a: $p$-value obtained on intergroup comparison using the Student's t-test for independent samples; $b$ : $p$-value obtained on intergroup comparison using the Mann-Whitney U test. 


\section{Results}

The findings of this study demonstrated no intergroup differences in the mobility, flexibility or endurance of torso flexors and lateral flexors. However, differences were observed in trunk extensor endurance and lateral flexor stability (difference between the right and left lateral flexors).

With respect to lumbar spine mobility, all the sailors were within normal parameters [22, 23], with no intergroup differences. The results seem to suggest that lumbar spine mobility was not related to pain in the subjects studied here.

Although there were no intergroup differences in flexibility, both the LBP and NLBP exhibited reduced flexibility when compared to normal values. Values below $80^{\circ}$ in the PSLR test and any compensatory hip flexion or knee extension movements in the modified Thomas test clinically established the presence of shortening in these muscle groups $[17,26]$.

Although all the participants displayed belownormal flexibility, indicating that this variable was not related to low back pain, poor flexibility in sailors can influence the mechanics of movement, requiring repeated compensatory movements during sailing and thereby contributing to injury.

With respect to trunk muscle endurance testing, contrary to what was expected, sailors with LBP showed better extensor endurance than those without LBP. Comparison of the results obtained with minimum detectable change (MDC) values reported in the literature [27] indicated a clinically important intergroup difference. As such, the athletes with LBP may have undergone specific training for these muscles in order to reduce pain and prevent the condition from worsening, resulting in better physical conditioning when compared to those with no pain who may not have paid much attention to this muscle group.

Both groups obtained holding times below $198 \mathrm{sec}-$ onds, which, according to Biering-Sorensen $[14,16]$, is a predictive factor for the development of LBP in men. The mean values recorded in the NLBP group were lower than those obtained by healthy men of different ages [28] and even sedentary individuals [15, 27], which is surprising given the high competitive level (national) of the athletes studied here. However, poor performance in this test could suggest long-term development of low back pain.

Thus, studies with larger populations are important to determine whether these muscle imbalances occur due to the physical demands of the sport and if they are influenced by the type of boat used, thereby establishing the possible factors related to the emergence of injuries and low back pain in these athletes.

Leetun et al. [29] studied 140 university athletes from different sports (80 women and 60 men) and found that those with low back pain (at least one episode that caused them to miss part of the season) generally obtained lower core stability values than those who experienced no pain episodes. In the present study, low back pain in the last seven days was a criterion for allocation into the LBP group. Nevertheless, it is possible that those with no low back pain (NLBP) had a history of this condition, which may have influenced the final results. Additionally, muscle endurance tests may not be a suitable assessment tool for individuals with LBP.

Another aspect to consider is that the hiking movement performed by sailors requires prolonged activation of the trunk flexors [30], meaning that training routines emphasize these muscles, which may partially explain the poor performance in trunk extensor muscle tests.

As such, this parameter needs to be better developed during the physical conditioning of these athletes by including core strength training, for example [31]. Moffroid et al. [13] reported a $22 \%$ increase in the holding time of trunk extensor muscles after a six-week (twelve sessions) basic exercise program.

Although the trunk flexor and lateral flexor endurance values obtained here are similar to those described in the literature $[23,27,32]$, there is an important difference in the balance between them in the LBP group when compared to the NLBP $(p=0.030)$, with a longer holding time on the right side than the left. This result suggests an imbalance between the lateral muscle chains of the torso in the LBP group, since the lateral flexor endurance test demonstrates activation of the gluteus medius, a hip stabilizer [33]. A study of golfers found that those with a difference of more than 12.5 seconds between the right and left sides in lateral trunk muscle endurance testing were more likely to experience pain episodes in the next ten months [34].

Hip dysfunctions such as muscle weakness and reduced range of motion are associated with pathologies of the lower back and legs. There is currently a moderate relationship between hip disorders and low back pathologies [33]. As such, the muscle imbalance exhibited by the LBP group may be partially responsible for their low back pain and should be addressed in the training and/or rehabilitation of these athletes. 
This study had some limitations. First, the population is highly specific, limited (national-level sailors) and generally difficult to access given their geographic distribution in the country. In addition, the data were collected at peak sporting performance and sample size was not calculated, which may have compromised statistical power to identify intergroup differences and enable generalization of the results. The cross-sectional design is also a limitation in relation to a prospective approach when investigating the relationship between the variables studied and low back pain. Our results could contribute to improving knowledge regarding prevention and rehabilitation, but should be considered preliminary and interpreted with caution. Future studies should aim to understand the biomechanical and musculoskeletal disorders present in sailors.

\section{Conclusion}

Sailors with low back pain exhibited a greater imbalance in muscle endurance between the right and left lateral muscle chains of the torso and better trunk extensor endurance than those who did not report this condition. Regardless of the presence of low back pain, all the sailors analyzed displayed low lumbar spine mobility, hip flexibility and trunk extensor endurance.

\section{References}

1. Fatoye F, Gebrye T, Odeyemi I. Real world incidence and prevalence of low back pain: a systematic review. Value Health. 2018;21(S1):S193.

2. Farahbakhsh F, Rostami M, Noormohammadpour P, Zade AM, Hassanmirazaei B, Jouibari MF, et al. Prevalence of low back pain among athletes: a systematic review. J Back Musculoskelet Rehabil. 2018;31(5):901-16.

3. Trompeter K, Fett D, Platen P. Prevalence of back pain in sports: a systematic review of the literature. Sports Med. 2017;47(6):1183-207.

4. Trompeter K, Fett D, Brüggemann GP, Platen P. Prevalence of back pain in elite athletes. Dtsch Z Sportmed. 2018;69(7-8):240-6.
5. Moraes J, Nery C, Fontel E, Morais E, Cosendey F, Rossatto $\mathrm{S}$, et al. Multidisciplinary assessment of the Brazilian Olympic sailing team. In: Legg SJ, Mackie H, Cochrane D (Eds). Human performance in sailing conference proceedings: incorporating the 4th European Conference on Sailing Sports Science and Sports Medicine and the 3rd Australian Sailing Science Conference. Palmerston North, New Zealand: Massey University; 2003. p. 92-5.

6. Bøymo-Having L, Grävare M, Silbernagel KG. A prospective study on dinghy sailors training habits and injury incidence with a comparison between elite sailor and club sailor during a 12-month period. Br J Sports Med 2013;47(13):826-31.

7. Tan B, Leong D, Vaz Pardal C, Lin CY, Kam JW. Injury and illness surveillance at the International Sailing Federation Sailing World Championships 2014. Br J Sports Med. 2016;50(11):673-81.

8. Schultz AB, Taaffe DR, Blackburn M, Logan P, White D, Drew $\mathrm{M}$, et al. Musculoskeletal screening as a predictor of seasonal injury in elite Olympic class sailors. J Sci Med Sport. 2016;19(11):903-9.

9. Cunningham P, Hale T. Physiological responses of elite Laser sailors to 30 minutes of simulated upwind sailing. J Sports Sci. 2007;25(10):1109-16.

10. Vogiatzis I, Tzineris D, Athanasopoulos D, Georgiadou O, Geladas N. Quadriceps oxygenation during isometric exercise in sailing. Int J Sports Med. 2008;29(1):11-5.

11. Legg SJ, Mackie H, Smith P. Temporal patterns of physical activity in Olympic dinghy racing. J Sports Med Phys Fitness. 1999;39(4):315-20.

12. Schütz GR, Roesler H, Haupenthal A, Bertaco CL, Pereira SM. Quantificação dos movimentos em regata da classe laser. Anais da Reunião da Sociedade Brasileira para o Progresso da Ciência - SBPC; 2004; Cuiabá: UFMT; 2004. p. 56.

13. Moffroid MT, Haugh LD, Haig AJ, Henry SM, Pope MH Endurance training of trunk extensor muscles. Phys Ther. 1993;73(1):10-7.

14. Biering-Sørensen FIN. Physical measurements as risk indicators for low-back trouble over a one-year period. Spine. 1984;9(2):106-19.

15. Jalayondeja W, Kraingchieocharn S. Trunk extensor, flexor and lateral flexor endurance time in sedentary workers aged 20-49 years. J Med Assoc Thai. 2015;98(Suppl. 5):S23-8. 
16. Latimer J, Maher CG, Refshauge K, Colaco I. The reliability and validity of the Biering-Sorensen test in asymptomatic subjects and subjects reporting current or previous nonspecific low back pain. Spine. 1999;24(20):2085-9.

17. Johnson EN, Thomas JS. Effect of hamstring flexibility on hip and lumbar spine joint excursions during forward reaching tasks in individuals with and without low back pain. Arch Phys Med Rehabil. 2010;91(7):1140-2.

18. Stutchfield BM, Coleman S. The relationships between hamstring flexibility, lumbar flexion, and low back pain in rowers. Eur J Sport Sci. 2006;6(4):255-60.

19. Kendal FP, McCreary EK. Muscles: testing and functions. 5th ed. Philadelphia: Lippincot; 2005.

20. Bellew S, Ford H, Shere E. The relationship between hamstring flexibility and pelvic rotation around the hip during forward bending. Plymouth Stud J Health Social Work. 2010;2:19-29.

21. Kostański L, Frąckowiak M, Pospieszna B. Back pain in Optimist sailors. Trends Sport Sci. 2019;2(26):63-9.

22. Castro MP, Stebbings SM, Milosavlievic S, Bussey M. Construct validity of clinical spinal mobility tests in ankylosing spondylitis: a systematic review and meta-analysis. Clin Rheumatol. 2016;35(7):1777-87.

23. Sarraf TA, Dezan VH, Rodacki ALF. Diferenças entre medidas quali e quantitativas durante testes de comprimento músculo-tendíneos dos flexores do quadriluni e biarticulares. Rev Bras Fisioter. 2005;9(2):195-202.

24. Gajdosik RL, Albert CR, Mitman JJ. Influence of hamstring length on the standing position and flexion range of motion of the pelvic angle, lumbar angle and thoracic angle. J Orthop Sports Phys Ther. 1994;20(4):213-9.

25. McGill SM, Childs A, Liebenson C. Endurance times for low back stabilization exercises: clinical targets for testing and training from a normal database. Arch Phys Med Rehabil. 1999;80(8):941-4.
26. Harvey D. Assessment of the flexibility of elite athletes using the modified Thomas test. Br J Sports Med. 1998;32(1):68-70.

27. Oliveira IO, Pilz B, Santos Jr LRG, Vasconcelos RA, Mello W, Grossi DB. Reference values and reliability for lumbopelvic strength and endurance in asymptomatic subjects. Braz J Phys Ther. 2018;22(1):33-41.

28. Adedoyin RA, Mbada CE, Farotimi AO, Johnson OE, Emechete AAI. Endurance of low back musculature: normative data for adults. J Back Musculoskelet Rehabil. 2011;24(2):101-9.

29. Leetun DT, Ireland ML, Willson JD, Ballantyne BT, Davis IM. Core stability measures as risk factors for lower extremity injury in athletes. Med Sci Sports Exerc. 2004;36(6):926-34.

30. Ruschel C, Jacomel GF, Schütz GR, Haupenthal A, Hubert M, Roesler H. Análise cinesiológica do movimento de escora de velejadores da classe laser em diferentes posições do barco em relação ao vento. Rev Educ Fis/ UEM. 2008;19(4):501-8.

31. Adegoke BOA, Babatunde FO. Effect of an exercise protocol on the endurance of trunk extensor muscles - a randomized control trial. Hong Kong Physiother J. 2007;25(1):2-9.

32. Evans K, Refshauge KM, Adams R. Trunk muscle endurance tests: reliability, and gender differences in athletes. J Sci Med Sport. 2007;10(6):447-55.

33. Reiman MP, Bolgla LA, Loudon JK. A literature review of studies evaluating gluteus maximus and gluteus medius activation during rehabilitation exercises. Physiother Theory Pract. 2012;28(4):257-68.

34. Evans K, Refshauge KM, Adams R, Aliprandi L. Predictors of low back pain in young elite golfers: A preliminary study. Phys Ther Sport. 2005;6(3):122-30.

Received: 03/25/2019

Recebido: 25/03/2019

Approved: 02/03/2020

Aprovado: 03/02/2020 